\title{
Soil formation in high elevation and permafrost areas in the Qinghai Plateau (China)
}

\author{
Edafogénesis en zonas elevadas y con permafrost en el Plateau Qunghai (China) \\ Formação do solo em áreas de elevada altitude e em ambientes"permafrost" do planalto \\ de Qinghai Plateau (China)
}

\section{AUTHORS}

\section{ArocenaJ.@1} arocenaj@unbc.ca

\section{Hall K. ${ }^{1}$}

Zhu L.P. ${ }^{2}$

@ Corresponding Author

${ }^{1}$ College of Science and Management, University of Northern British Columbia. 3333 University Way, Prince George, BC, Canada V2N4Z9.

${ }^{2}$ Institute of Tibetan Plateau Research, Chinese Academy of Sciences. Beijing 100101, China.
Received: 20.02.2012 | Revised: 25.05.2012 | Accepted: 05.06.2012

\section{ABSTRACT}

Soil systems continuously gain and lose matter and energy even in areas where climate is too harsh to support the higher plants such as in higher elevations and in permafrost environments. The purpose of this paper was to elucidate soil formation at $4700 \mathrm{~m}$ asl in the Kunlun Mountains of the Qinghai (Tibet) Plateau, China. We collected twenty-six samples from three pedons developed on carbonaterich slate and quartzitic-sandstone materials. The samples were analyzed for routine physical, chemical and mineralogical properties. Our results indicate that soil-forming processes are barely taking place in the study site as shown by $\mathrm{pH}>7.0$ reflecting limited decarbonation, biological activity $(<$ $1.0 \%$ total $\mathrm{C}$ and $<0.05 \%$ total $\mathrm{N})$, podzolization $\left(<1 \mathrm{~g} \mathrm{Fe}+\mathrm{Al}_{\mathrm{p}} \mathrm{kg}^{-1}\right.$ soil $)$ and lessivage. The relative amounts of mica and kaolinite show no apparent change with ${ }^{\mathrm{p}}$ depth suggesting minimal transformation and translocation of phyllosilicates. The most noticeable mineral transformation resulted in micaceous "flakes" and feldspathic "fragments" possibly due to thermal stress. Calcite is also observed coating the slate fragments. The soils are classified as Cryosols in the World Reference Base system and Gelisols in the Soil Taxonomy with ochric epipedon as the only diagnostic horizon indicating recent development of soils due to cold and arid environment. The results of this study show that soil-forming processes in harsh environments are manifested in the mechanical breakdown of minerals such as mica and feldspars.

\section{RESUMEN}

Los sistemas edáficos ganan y pierden continuamente materia y energía incluso en zonas donde el clima es demasiado severo como para permitir el desarrollo de plantas superiores, como son las zonas de elevada altitud - los ambientes con permafrost. El objetivo de este trabajo es analizar la formación del suelo a una altitud de $4700 \mathrm{~m}$ en las Montañas Kunlun del Qinghai (Tibet) Plateau, China. Se recogieron veintiséis muestras de tres perfiles desarrollados sobre pizarras ricas en carbonatos y areniscas cuarcíticas, que fueron analizadas para determinar sus propiedades físicas, químicas y mineralógicas. Los resultados mostraron que los procesos de formación del suelo apenas tienen lugar en la zona de estudio, evidenciados por el $p H>7,0$ que refleja una limitada descarbonatación, baja actividad biológica ( $<1,0 \% \mathrm{C}$ total y $<0,05 \% \mathrm{~N}$ total), y podsolización $\left(<1 \mathrm{~g} \mathrm{Fe}_{p}+\mathrm{Al}_{\mathrm{p}} \mathrm{kg}^{-1}\right.$ suelo) e iluviación limitadas. Las cantidades relativas de mica y caolinita no mostraron variaciones aparentes en profundidad, lo que sugiere una minima transformación y translocación de filosilicatos. La transformación mineral más aparente se mostró por la presencia de escamas micáceas y fragmentos feldespáticos, posiblemente debidos a estrés térmico. También se observaron revestimientos de calcita en fragmentos de pizarra. Los suelos se clasificaron como Criosoles (World Reference Base) y Gelisoles (Soil Taxonomy), con un epipedón ócrico como único horizonte de diagnóstico, indicando poca evolución de los suelos debido a ambiente frío y árido. Los resultados de este estudio muestran que los procesos de formación de suelo en ambientes severos se manifiestan por la alteración mecánica de minerales como las micas y los feldespatos. 


\section{RESUMO}

O sistema solo ganha e perde continuamente massa e energia mesmo em áreas em que o clima é demasiado severo para o desenvolvimento das plantas tais como áreas de elevada altitude e ambientes "permafrost". O objectivo deste trabalho foi esclarecer a formação do solo a uma altitude de $4700 \mathrm{~m}$ nas Montanhas de Kunlun (Tibete) no Planalto de Qinghai (China). Recolheram-se 26 amostras de três pedons desenvolvidos em ardósias carbonatadas e materiais areniticos quartzozos. As amostras foram submetidas a uma análise de rotina para caracterização das suas propriedades físicas, quimicas e mineralógicas. Os resultados indicam que os processos de formação do solo praticamente não ocorreram no local do estudo tal como demonstram os valores de $p H>7.0$ que reflectem uma reduzida descarbonatação, actividade biológica $(<1.0 \% \mathrm{C}$ total $e<0.05 \% \mathrm{~N}$ total $)$, podzolizaçấo $(<1 \mathrm{~g}$ $\mathrm{Fe}+\mathrm{Al} \mathrm{kg}^{-1}$ solo) e eluviação. As quantidades relativas de mica e caulinite presentes demonstam que não ocorreram alteraçôes aparentes em profundidade sugerindo uma tranformação e tranlocação minima dos filossilicatos. A transformação mineral de maior relevancia resultou na formação de "palhetas" de mica e "fragmentos" de feldspatos muito provavelmente devido a stress térmico. Ocorreu também o aparecimento de calcite a revestir os fragmentos de ardósia. Taxonomicamente e de acordo com a classificacão WRB os solos classificam-se como Criossolos e Gelissolos com epipedon ócrico com um único horizonte indicando recente desenvolvimento devido ao ambiente frio e árido. Os resultados deste estudo mostram que os processos de formação do solo em ambientes severos se manifestam pela fractura de minerais como a mica e o feldspato.

KEYWORDS

Cryosols, muscovite,

feldspar, kaolinite, diamicton, thermal stress, sandstone

PALABRAS

CLAVE

Criosoles, moscovita, feldespato, caolinita, diamicton, stress térmico, arenisca

PALAVRAS-

CHAVE

Criossolos, moscovite,

feldspato, caulinite, diamicton, stress térmico, arenitos 


\section{Introduction}

Soils are open systems where input/output of matter and energy continuously takes place. Soil parent material evolves to soils through addition, transformation, translocation and removal processes influenced by biotic, climatic and geomorphic factors (Van Breemen and Buurman 1998; Soil Survey Staff 2010; Buol et al. 2003). Soils are "active mixing zones of living and dead organic matter, water, a trace gas laden atmosphere, decaying rock minerals and residue of their interaction" (Chadwick and Chorover 2001). Traditionally, soil is mainly considered as a medium for plant growth but "the ability to support rooted plants in a natural environment" is no longer a requirement in the revised definition of soil (Soil Survey Staff 2010). The revised definition now includes "soils in areas of Antarctica where pedogenesis occurs, but where climate is too harsh to support the higher plant forms." Even if biological activity approaches zero, Campbell and Claridge (1987) argued that "leaching, mineral decay and segregation" are still taking place in the Antarctic. Beyer and Bölter (2000) reported that meltwater and moss layers are essential for the podzolization processes taking place in East Antarctica. Bockheim (1997) reported that soil-forming processes in cold and dry valleys in Antarctica are dominated by physical weathering with some degree of reduction and oxidation of iron, and accumulation of salts from precipitation. Situations similar to the cold Antarctic desert may exist in high elevation and permafrost areas (e.g., Qinghai Plateau, China) where the environment is characterized by a cold and dry climate that is not conducive to plant growth.

Harsh environmental conditions in Qinghai plateau limit the growth of higher plants but do not preclude soil formation because of continual input/output of matter and energy. For example, Wang et al. (2002) estimated that organic C stored in meadow and steppe soils in Qinghai Plateau amounts to $23.2 \mathrm{Pg} \mathrm{C}$ or the equivalent of $2.5 \%$ of global pool of soil carbon. According to previous investigations in Xizang and Hoh Xil regions in Qinghai Province, the soil in this area belongs to the alpine steppe soil (alpine desert-steppe sub-type) with $<100 \mathrm{~g}$ organic matter $\mathrm{kg}^{-1}$ soil (Li et al. 1996). In northeastern Tibetan plateau, input of precipitation with $\mathrm{pH}$ ranging from 6.3-8.2 is a steady occurrence in Qinghai Province, China (Zhang et al. 2003). Preliminary results of Yan et al. (2001) estimated the rate of wind erosion using ${ }^{137} \mathrm{Cs}$ as tracer for erosion and sedimentation in Qinghai Plateau to be $47.59 \mathrm{t} \mathrm{ha}^{-1}$ year ${ }^{-1}$. In other cold and dry environments such as in the Antarctic dry valleys, the scarcity of soil moisture and low temperature restricted the vegetation to isolated patches of mosses, lichens and small bacterial and invertebrate populations (Campbell and Claridge 1987). Mahaney et al. (2001) reported the presence of fungi (Beauveria and Penicillium genera) that are capable of producing organic compounds capable of chelating ions from the breakdown of soil minerals in dry valleys in Antarctica. Other studies documented that in cold environments, biological activity could be a major factor in landscape evolution including soil mineral transformation (e.g., Hall and Otte 1990; Etienne 2002; Etienne and Dupont 2002) such as transformation of muscovite to illite (Matsuoka 1995). In our previous study on granite weathering in Qinghai Plateau (Arocena et al. 2003), we observed secondary accumulations of 2:1 clays minerals on surfaces colonized by Aspicilia caesiocinera and oxides of manganese on granites inhabited by Xanthoria elegans.

The purpose of this paper was to describe various soil-forming processes in cold and dry environments to generate information that may be used to understand soil formation in similar conditions such as those in the permafrost zones in Arctic and Antarctica. Specifically, we determined the physical, chemical, biological and mineral properties of samples collected from three profiles to describe (if any) and classify the soils near a well-characterized large mass flow deposit (Harris et al. 1998a, 1998b) in cold and dry environment of the Kunlun Shan (mountains) in Qinghai Plateau (China). This large deposit of rocks or diamicton ranges from 4750 to 4900 (Harris et al. 1998a). Till deposits around this large diamicton has a permafrost depth from 12 to $30 \mathrm{~cm}$ in July (Harris et al. 1998a). 


\section{Materials and Methods}

- Selection of the study area and sample collection

The study area is located near the Kunlun Pass

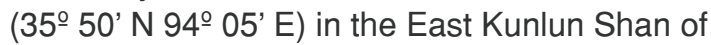
the Qinghai Plateau in the province of Qinghai, China (Figure 1). The site was selected based on an earlier study on the origin of diamicton in Kunlun Shan which is described by Harris et al. (1998a) as "the longest and most spectacular of such deposits described so far in the world". The sampling sites are situated in the transition zone between alpine meadow and alpine cold desert (Figure 1). The elevation of the study area varies from 4800 to $5000 \mathrm{~m}$ asl with a mean annual air temperature of $-5.5{ }^{\circ} \mathrm{C}$ and an estimated mean annual precipitation of $280 \mathrm{~mm}$ (Zhou et al. 2000 , p. 232; Zhao 1994, p. 34); permafrost underlies the study area at various depths depending on the slope aspect. The bedrock in the sampling area is dominated by slate and quartzsandstone. Glacial erratics of granitic origin are also common in the area. The present day geomorphic features in the study area are due to an abrupt uplift of the plateau during the Early and Middle Pleistocene (Wu et al. 2001). Harris et al. (1998a, 1998b) claimed that materials in the diamicton in their study area were derived from Middle Pleistocene tills and Pliocene alluvial gravels. The vegetation in the area is dominated by alpine/tundra meadows such as Carex, Saussurea, Leontopodium, Aster, Taraxicum and Polygonium (Harris et al. 1998a, 1998b). The sampling sites have sparse alpine vegetation consisting of Saussurea gnaphalodes, S. hypsipeta, Arenaria bryophylla, Oxytropis densa, Astragalus densiflorus and Carex moorcroftii ( $\mathrm{Li}$ et al. 1996, p. 113).

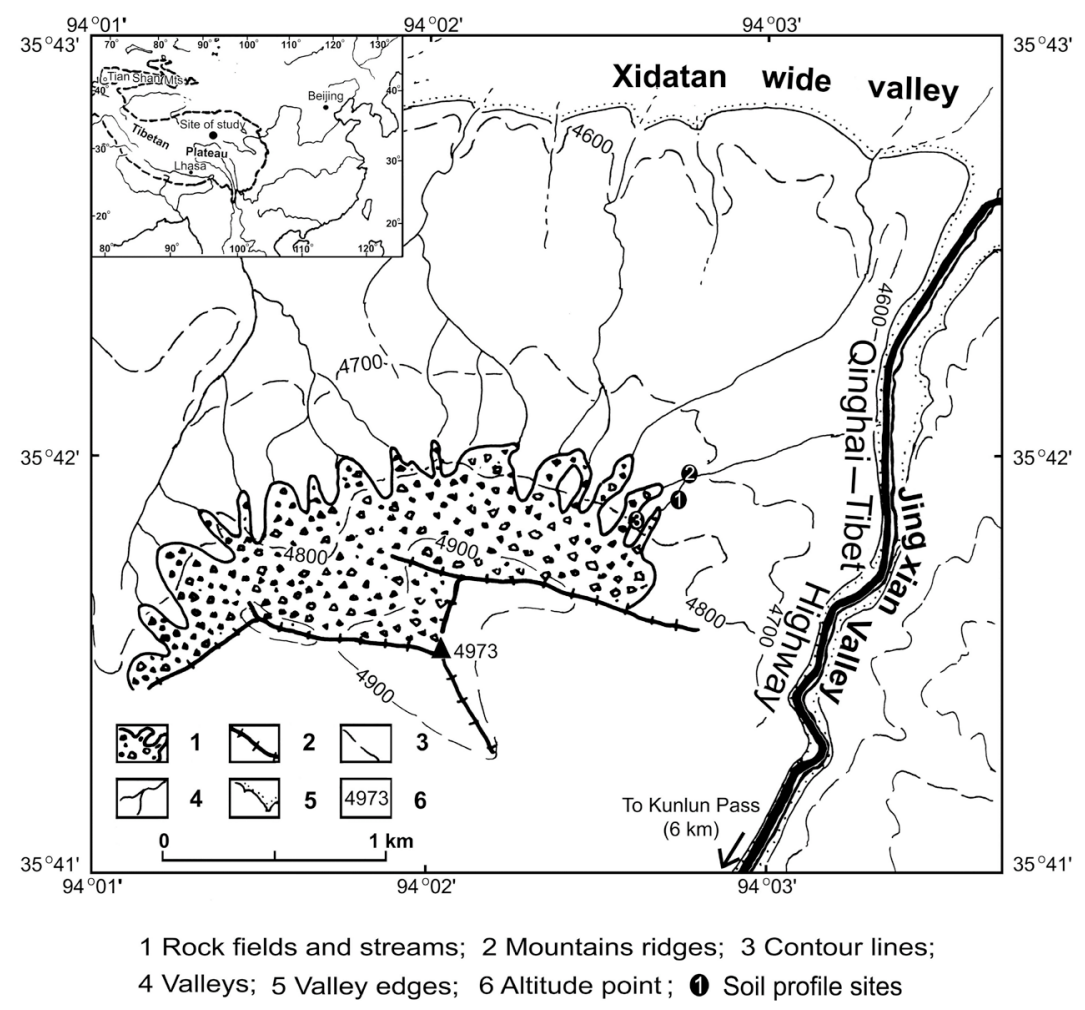

Figure 1. Location of the study area and the relative locations of the soil profiles. Contour lines and altitude points are in meters. 
Twenty six soil samples from three profiles developed in slate and quartz-sandstone parent geological materials were collected in June 2001. Soil profiles were dug at the end of a rock stream with west to east orientation in Kunlun Shan with varying thickness to the permafrost table. Profile 1 has a southeast orientation (220 $\mathrm{cm}$ thick) while Profile 2 (130 cm thick) and 3 (92 $\mathrm{cm}$ thick) have slope aspects of northeast and north, respectively. Approximately $500 \mathrm{~g}$ of soil sample from each layer were collected in plastic bags and transported to the laboratory at the University of Northern British Columbia (Prince George, BC Canada) for chemical, physical and mineralogical analyses. The samples were transported in a regular cabin baggage at ambient temperature. Samples were immediately air dried upon arrival in Canada and ground to pass a $2 \mathrm{~mm}$ sieve prior to any analyses.

\section{- Physical and chemical properties of soils}

Particle size analysis was conducted on $<2$ $\mathrm{mm}$ air-dried samples using the pipette method (Kalra and Maynard 1991). We used ultra-sonic treatment for 6 minutes at $400 \mathrm{~W}$ to disperse soil samples prior to separation of sand from silt and clay. The sand fraction was separated from the silt and clay by wet-sieving through a $53 \mu \mathrm{m}$ sieve and the clay $(<2 \mu \mathrm{m})$ was separated from the silt through successive sedimentation and dispersion following the principle of Stoke's Law. Sub-samples of clay fraction were $\mathrm{Ca}$ - and $\mathrm{K}$ saturated for mineral analysis.

Soil $\mathrm{pH}$, cation exchange capacity and exchangeable cations were determined from airdried samples following methods outlined in Hendershot et al. (1993). Soil pH in $\mathrm{H}_{2} \mathrm{O}$ and $0.01 \mathrm{M} \mathrm{CaCl}_{2}$ was determined from separate slurry composed of 2:1 solution:soil ratio using an electronic $\mathrm{pH}$ meter. Total $\mathrm{C}$ and $\mathrm{N}$ were determined by dry combustion using Carlo Erba NA1500 Elemental Analyzer with atropine as internal standard. Cation exchange capacity was determined with $1.0 \mathrm{M} \mathrm{NH}_{4} \mathrm{OAc}$ buffered at $\mathrm{pH}$ 7.0 as the displacing solution and exchangeable $\mathrm{Ca}^{2+}, \mathrm{Mg}^{2+}, \mathrm{K}^{+}$and $\mathrm{Na}^{+}$in the extract were determined using inductively coupled plasma atomic emission spectrometer. Various forms of extractable Al, $\mathrm{Fe}, \mathrm{Mn}$ and Si were determined from the following extracts (1) dithionite-citrate-bicarbonate, (2) acid ammonium oxalate, and (3) sodium pyrophosphate (Ross and Wang 1993).

\section{- Soil minerals}

The mineral composition of samples was determined by X-ray diffraction (XRD) using a Bruker D8/GADDS X-ray diffraction unit operated at $40 \mathrm{kV} 20 \mathrm{~mA}$ to generate Co Ka radiation. The clay fraction sample was prepared for X-ray analysis following the paste method (Theisen and Harward 1962) for both K- and Ca-saturated samples. The Ca-saturated clay sample was solvated with glycerol (Gly) and ethylene glycol (EG) while the K-saturated sample was heated for 2 hours at 300 and $550^{\circ} \mathrm{C}$. Ca and K-saturated samples were also scanned at ambient temperature and relative humidity. Identification of minerals in the clay fraction was based on the following criteria: (1) mica $-1.0 \mathrm{~nm}$ reflection in all treatments, (2) kaolinite $-0.712 \mathrm{~nm}$ reflection that disappeared after $550{ }^{\circ} \mathrm{C}$ heat treatment of K-saturated clay, and (4) 2:1 type expandable clays- $1.7 \mathrm{~nm}$ reflection in Ca-Gly. Minerals in sand and silt fractions were determined in ground samples mounted randomly on glass slide using mineral oil and scanned from 3 to $90^{\circ} 2 \theta$. In addition, a Philips XLS-30 scanning electron microscope with energy dispersive system (EDS) was used to describe the minerals present in sand and silt fraction using morphology and semi-quantitative elemental composition determined EDS. We also determined the mineralogy of slate and sandstone to help us understand the origin of clays present in each horizon. 


\section{Results}

- Physical and chemical properties

Table 1 shows selected properties of soils in our study area. Soils are sandy in texture containing between $58-87 \%$ sand and are calcareous with $\mathrm{pH}_{\text {water }}$ values ranging from $\mathrm{pH}$ 6.8-8.1. Organic matter (OM) content is low $(<0.10$ and $<2.0 \%$ total $\mathrm{N}$ and $\mathrm{C}$, respectively) and exhibits a typical uniformity with depth. The amount of exchangeable $\mathrm{Ca}^{2+}$ generally exceeds cation exchange capacity (CEC) due to the presence of carbonates as indicated by $\mathrm{pH}>7.0$. Relative amounts of exchangeable cations follow the trend $\mathrm{Ca}^{2+}>$ $\mathrm{Mg}^{2+}>>\mathrm{Na}^{+}>\mathrm{K}^{+}$and except for Bw3 and Bw5, the exchange complex of soils is $<0.10$ sodium saturated.

Table 1: Selected properties of soil samples collected from the Qinghai Plateau, China

$\begin{array}{cccccccccccc}\text { Depth } & \begin{array}{c}\text { Color } \\ \text { (dry) }\end{array} & \text { Silt } & \text { Clay } & \begin{array}{c}\mathrm{pH} \\ \mathrm{H}_{2} \mathrm{O}\end{array} & \begin{array}{c}\mathrm{pH} \\ \mathrm{CaCl}_{2}\end{array} & \text { Total N } & \text { Total C } & \mathrm{CEC} & \mathrm{Ca} & \mathrm{K} & \mathrm{Mg} \\ (\mathrm{cm}) & & (\%) & (\%) & & & (\%) & (\%) & & \left(\mathrm{cmol}_{\mathrm{c}} \mathrm{kg}^{-1} \text { soil) }\right.\end{array}$

\begin{tabular}{|c|c|c|c|c|c|c|c|c|c|c|c|c|c|}
\hline \multicolumn{14}{|c|}{ Profile \#1 } \\
\hline $\mathrm{A} 1$ & $0-20$ & 10YR 5/3 & 25 & 7.4 & 7.6 & 6.9 & 0.07 & 1.7 & 5.3 & 12.9 & 0.08 & 1.71 & 0.12 \\
\hline A2 & $20-50$ & 10YR 6/3 & 26 & 8.8 & 7.8 & 7.5 & 0.03 & 0.91 & 5.2 & 15.5 & 0.13 & 2.80 & 0.27 \\
\hline A3 & $50-80$ & 10YR 6/3 & 14 & 6.8 & 7.7 & 7.4 & 0.03 & 0.84 & 4.4 & 17.5 & 0.16 & 4.49 & 0.23 \\
\hline Bw & $80-126$ & $2.5 Y 6 / 2$ & 16 & 10 & 6.8 & 6.4 & 0.04 & 0.80 & 5.4 & 15.0 & 0.14 & 3.94 & 0.16 \\
\hline $\mathrm{C} / \mathrm{IIA} 1$ & $126-141$ & $2.5 Y 7 / 3$ & 12 & 5.8 & 7.4 & 7.2 & 0.02 & 1.3 & 5.4 & 15.9 & 0.25 & 5.74 & 0.21 \\
\hline IIA2 & $141-156$ & 10YR $7 / 2$ & 17 & 7.6 & 7.6 & 6.9 & 0.02 & 0.92 & 5.8 & 13.8 & 0.20 & 5.29 & 0.21 \\
\hline IIBw1 & $156-171$ & $2.5 Y 6 / 2$ & 20 & 17 & 7.7 & 7.2 & 0.05 & 0.29 & 9.0 & 5.07 & 0.16 & 5.54 & 0.20 \\
\hline IIBw2 & $171-180$ & $2.5 Y 5 / 2$ & 18 & 11 & 7.4 & 7.2 & 0.04 & 0.37 & 11.0 & 5.31 & 0.24 & 7.72 & 0.30 \\
\hline IIBw3 & $180-205$ & $2.5 Y 6 / 1$ & 19 & 13 & 7.9 & 7.0 & 0.06 & 0.41 & 9.0 & 4.80 & 0.41 & 9.65 & 0.74 \\
\hline IIC & $205-220$ & $2.5 Y 6 / 2$ & 17 & 13 & 7.9 & 7.0 & 0.04 & 0.71 & 6.8 & 4.88 & 0.33 & 9.43 & 0.67 \\
\hline \multicolumn{14}{|c|}{ Profile \#2 } \\
\hline Bw1 & $0-50$ & $2.5 Y 7 / 3$ & 18 & 15 & 7.6 & 7.4 & 0.04 & 0.91 & 5.4 & 13.2 & 0.20 & 3.36 & 0.87 \\
\hline Bw2 & $50-59$ & $2.5 Y 7 / 2$ & 16 & 9.6 & 7.2 & 7.2 & 0.04 & 1.4 & 5.4 & 14.7 & 0.18 & 3.70 & 0.50 \\
\hline Bw3 & $59-70$ & $2.5 Y 8 / 2$ & 10 & 7.7 & 8.1 & 7.3 & 0.04 & 1.4 & 4.4 & 9.66 & 0.20 & 6.46 & 0.17 \\
\hline Bw4 & $70-82$ & $2.5 Y 8 / 2$ & 18 & 9.6 & 7.8 & 6.9 & 0.05 & 0.92 & 5.7 & 9.95 & 0.19 & 6.23 & 1.42 \\
\hline Bw5 & $82-87$ & $2.5 Y 8 / 3$ & 17 & 8.3 & 7.4 & 7.0 & 0.04 & 1.0 & 5.2 & 18.0 & 0.15 & 6.25 & 0.14 \\
\hline Bw6 & $87-101$ & $2.5 Y 8 / 2$ & 22 & 9.9 & 8.0 & 7.2 & 0.04 & 0.89 & 5.4 & 6.69 & 0.21 & 8.87 & 0.23 \\
\hline Bw7 & $101-118$ & $2.5 Y 8 / 3$ & 16 & 8.6 & 7.8 & 7.4 & 0.04 & 0.77 & 5.2 & 5.69 & 0.18 & 8.45 & 0.29 \\
\hline Bw8 & $118-130$ & $2.5 Y 8 / 2$ & 18 & 9.3 & 7.8 & 7.4 & 0.06 & 0.80 & 4.3 & 3.75 & 0.17 & 7.70 & 0.22 \\
\hline \multicolumn{14}{|c|}{ Profile \#3 } \\
\hline $\mathrm{A} 1$ & $0-20$ & $2.5 Y 6 / 3$ & 10 & 2.7 & 7.0 & 6.9 & 0.03 & 0.65 & 2.2 & 4.55 & 0.20 & 8.87 & 0.19 \\
\hline $\mathrm{A} 2$ & $20-38$ & 10YR 6/3 & 24 & 8.0 & 7.0 & 7.0 & 0.04 & 0.63 & 3.8 & 15.6 & 0.09 & 2.38 & 0.24 \\
\hline Bw1 & $38-45$ & $2.5 Y 6 / 2$ & 24 & 12 & 7.6 & 6.8 & 0.05 & 0.44 & 7.7 & 20.9 & 0.17 & 3.05 & 0.24 \\
\hline Bw2 & $45-51$ & $2.5 Y 7 / 3$ & 25 & 12 & 7.6 & 7.3 & 0.04 & 0.43 & 6.1 & 15.4 & 0.22 & 4.64 & 0.22 \\
\hline Bw3 & $51-70$ & $2.5 Y 6 / 3$ & 22 & 10 & 7.4 & 6.7 & 0.04 & 0.54 & 6.0 & 9.48 & 0.24 & 6.64 & 0.74 \\
\hline Bw4 & $70-92$ & $2.5 Y 6 / 3$ & 27 & 9.2 & 7.5 & 7.4 & 0.04 & 0.62 & 4.1 & 18.0 & 0.20 & 4.07 & 0.19 \\
\hline C & $92+$ & $2.5 Y 8 / 3$ & 12 & 7.5 & 7.2 & 6.4 & 0.04 & 1.4 & 9.5 & 19.5 & 0.17 & 3.62 & 0.14 \\
\hline
\end{tabular}


Extractable $\mathrm{Al}, \mathrm{Fe}$ and $\mathrm{Mn}$ in pyrophosphate, acid ammonium oxalate and dithionite-citrate methods are given in Table 2. The amount of $\mathrm{Al}, \mathrm{Fe}$ and $\mathrm{Mn}$ complexed with soil humus as estimated by alkaline sodium pyrophosphate method is very low $(<0.01 \%)$ for all soils in the study. Extractable $\mathrm{Al}$ and $\mathrm{Mn}$ in acid oxalate and dithionite-citrate methods are $<0.01 \%$. Fe $e_{\text {old }}$ ratio is the proportion of $\mathrm{Fe}_{\mathrm{o}}$ and $\mathrm{Fe}_{\mathrm{d}}$ (the higher the ratio, the lower the crystallinity of iron oxides) in Profiles 1 ranges from 0.07 to 0.97 and from 0.13 to 0.26 in Profile 3 except in C horizon of Profile 3 where $\mathrm{Fe}_{\mathrm{o} / \mathrm{d}}=1.50$. In Profile 2, $\mathrm{Fe}_{\mathrm{o} / \mathrm{d}}$ ratio ranges from 1.3 to 3.8 .

Table 2: Extractable Al, Fe and $\mathrm{Mn}$ and optical density of oxalate extract (ODOE) in soil samples collected from the Qinghai Plateau, China

\begin{tabular}{|c|c|c|c|c|c|c|c|c|c|c|}
\hline $\begin{array}{l}\text { Depth } \\
(\mathrm{cm})\end{array}$ & $\begin{array}{c}\mathrm{Al}_{\mathrm{p}} \\
\left(\mathrm{mg} \mathrm{kg}^{-1}\right)\end{array}$ & $\begin{array}{c}\mathrm{Fe}_{\mathrm{p}} \\
\left(\mathrm{mg} \mathrm{kg}^{-1}\right)\end{array}$ & $\begin{array}{c}\mathrm{Mn}_{\mathrm{p}} \\
\left(\mathrm{mg} \mathrm{kg}^{-1}\right)\end{array}$ & $\begin{array}{l}\mathrm{Al}_{\circ} \\
(\%)\end{array}$ & $\begin{array}{l}\mathrm{Fe}_{\circ} \\
(\%)\end{array}$ & $\begin{array}{l}\mathrm{Mn}_{\mathrm{o}} \\
(\%)\end{array}$ & $\begin{array}{l}\mathrm{Al}_{\mathrm{d}} \\
(\%)\end{array}$ & $\begin{array}{l}\mathrm{Fe}_{\mathrm{d}} \\
(\%)\end{array}$ & $\begin{array}{l}\mathrm{Mn}_{\mathrm{d}} \\
(\%)\end{array}$ & $\mathrm{Al}_{\mathrm{o} / \mathrm{d}}$ \\
\hline
\end{tabular}

\begin{tabular}{|c|c|c|c|c|c|c|c|c|c|c|c|c|}
\hline \multicolumn{13}{|c|}{ Profile \#1 } \\
\hline A1 & $0-20$ & 64 & 180 & 72 & 0.07 & 0.42 & 0.02 & 0.07 & 1.5 & 0.04 & 0.93 & 0.28 \\
\hline A2 & $20-50$ & 18 & 34 & 28 & 0.05 & 0.72 & 0.02 & 0.07 & 2.4 & 0.03 & 0.64 & 0.30 \\
\hline A3 & $50-80$ & 24 & 49 & 45 & 0.06 & 0.96 & 0.02 & 0.08 & 2.5 & 0.04 & 0.79 & 0.38 \\
\hline $\mathrm{Bw}$ & $80-126$ & 17 & 35 & 36 & 0.05 & 0.74 & 0.03 & 0.07 & 2.6 & 0.03 & 0.67 & 0.28 \\
\hline $\mathrm{C} / \mathrm{IIA} 1$ & $126-141$ & 28 & 17 & 12 & 0.05 & 2.9 & 0.07 & 0.03 & 3.4 & 0.08 & 1.6 & 0.84 \\
\hline IIA2 & $141-156$ & 21 & 73 & 33 & 0.04 & 1.8 & 0.06 & 0.02 & 1.8 & 0.05 & 1.7 & 0.98 \\
\hline IIBw1 & $156-171$ & 38 & 9 & 8 & 0.04 & 0.25 & 0.04 & 0.04 & 3.6 & 0.05 & 0.97 & 0.07 \\
\hline IIBw2 & $171-180$ & 31 & 140 & 59 & 0.04 & 0.40 & 0.06 & 0.03 & 2.3 & 0.04 & 1.3 & 0.17 \\
\hline IIBw3 & $180-205$ & 33 & 13 & 8 & 0.04 & 1.1 & 0.03 & 0.03 & 1.6 & 0.02 & 1.5 & 0.64 \\
\hline IIC & $205-220$ & 43 & 33 & 18 & 0.04 & 1.2 & 0.05 & 0.03 & 1.9 & 0.04 & 1.3 & 0.65 \\
\hline \multicolumn{13}{|c|}{ Profile \#2 } \\
\hline Bw1 & $0-50$ & 40 & 61 & 31 & 0.10 & 1.6 & 0.02 & 0.06 & 1.2 & 0.02 & 1.6 & 1.4 \\
\hline Bw2 & $50-59$ & 35 & 48 & 12 & 0.07 & 1.4 & 0.02 & 0.04 & 0.78 & 0.01 & 1.7 & 1.8 \\
\hline Bw3 & $59-70$ & 34 & 27 & 8 & 0.05 & 1.1 & 0.02 & 0.04 & 0.82 & 0.01 & 1.4 & 1.3 \\
\hline Bw4 & $70-82$ & 41 & 27 & 19 & 0.04 & 0.96 & 0.02 & 0.02 & 0.40 & 0.01 & 1.8 & 2.4 \\
\hline Bw5 & $82-87$ & 28 & 27 & 7 & 0.04 & 1.2 & 0.02 & 0.02 & 0.42 & 0.01 & 1.8 & 2.8 \\
\hline Bw6 & $87-101$ & 79 & 47 & 14 & 0.06 & 0.93 & 0.02 & 0.02 & 0.24 & 0.004 & 2.5 & 3.9 \\
\hline Bw7 & $101-118$ & 64 & 35 & 8 & 0.05 & 1.1 & 0.01 & 0.03 & 0.42 & 0.004 & 1.9 & 2.5 \\
\hline Bw8 & $118-130$ & 42 & 35 & 5 & 0.04 & 1.1 & 0.01 & 0.02 & 0.45 & 0.004 & 1.7 & 2.3 \\
\hline \multicolumn{13}{|c|}{ Profile \#3 } \\
\hline A1 & $0-20$ & 23 & 39 & 47 & 0.04 & 0.29 & 0.02 & 0.10 & 2.2 & 0.05 & 0.37 & 0.13 \\
\hline A2 & $20-38$ & 15 & 28 & 33 & 0.05 & 0.32 & 0.04 & 0.10 & 2.4 & 0.05 & 0.47 & 0.14 \\
\hline Bw1 & $38-45$ & 22 & 20 & 20 & 0.04 & 0.44 & 0.04 & 0.07 & 2.9 & 0.04 & 0.53 & 0.15 \\
\hline Bw2 & $45-51$ & 26 & 23 & 10 & 0.03 & 0.70 & 0.04 & 0.04 & 2.6 & 0.04 & 0.77 & 0.26 \\
\hline Bw3 & $51-70$ & 21 & 25 & 28 & 0.03 & 0.43 & 0.03 & 0.08 & 2.5 & 0.05 & 0.40 & 0.17 \\
\hline Bw4 & $70-92$ & 15 & 29 & 45 & 0.03 & 0.33 & 0.04 & 0.09 & 2.3 & 0.05 & 0.37 & 0.14 \\
\hline C & $92+$ & 121 & 162 & 17 & 0.04 & 1.5 & 0.02 & 0.03 & 1.0 & 0.01 & 1.6 & 1.5 \\
\hline
\end{tabular}


- Soil minerals

The presence of intense X-ray reflections at $0.998,0.717$ and $0.500 \mathrm{~nm}$ regions in $\mathrm{Ca}$ - and K-saturated samples at $54 \% \mathrm{RH}$ and the absence of reflections at $1.6 \mathrm{~nm}$ region in both $\mathrm{Ca}$ Gly and $\mathrm{Ca}-\mathrm{EG}$ treatments indicate that muscovite and kaolinite are the main minerals in clay fraction of soils in our study area (Figure 2). The dominance of low-charge phyllosilicates in soil samples is consistent with the low CEC $(<10$ $\mathrm{cmol}_{\mathrm{c}} \mathrm{kg}^{-1}$ soil). Based on the relative intensities of the X-ray reflections at 0.998 and $0.717 \mathrm{~nm}$ regions, estimates of muscovite and kaolinite contents in various horizons show similarity within and among the three soil profiles.
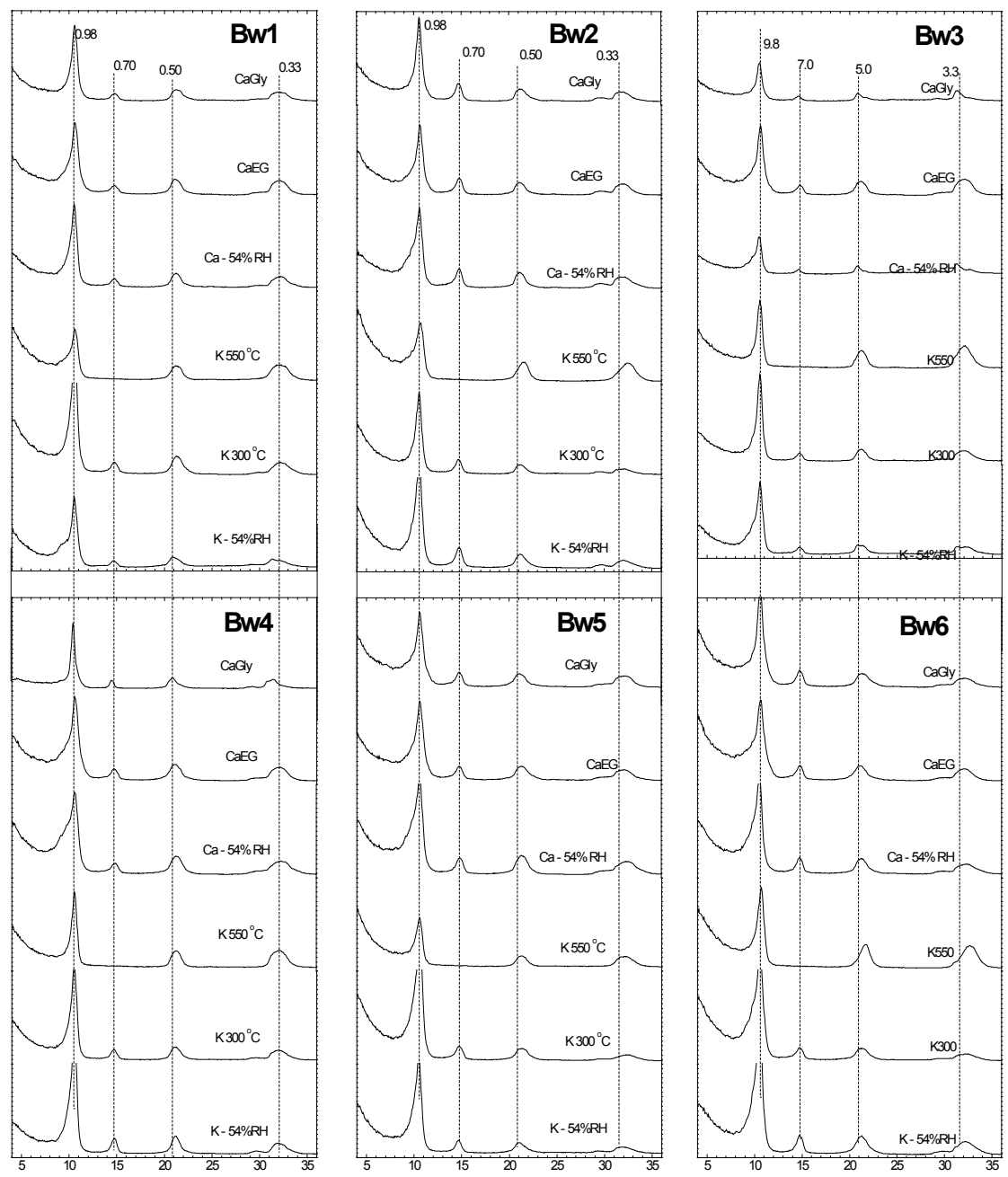

$\mathrm{CuK \alpha}{ }^{\circ} 2 \theta$

Figure 2. X-ray diffractograms of clay samples from Profile 2 under different pre-treatments (see Materials and Methods section for sample identification and description of various treatments). 
Moreover, "flakes" of micaceous minerals (Figures $3 \mathrm{~A}$ and $\mathrm{C}$ ) accumulate on the surface of slate parent material while "fragments" of feldspars with smooth surface (Figures $3 \mathrm{~B}$ and $\mathrm{D}$ ) ac- cumulate on the surface of sandstone parent material. X-ray diffraction patterns of the slate and "flakes" in A1 horizon of Profile 1 show very strong similarity and indicate the presence
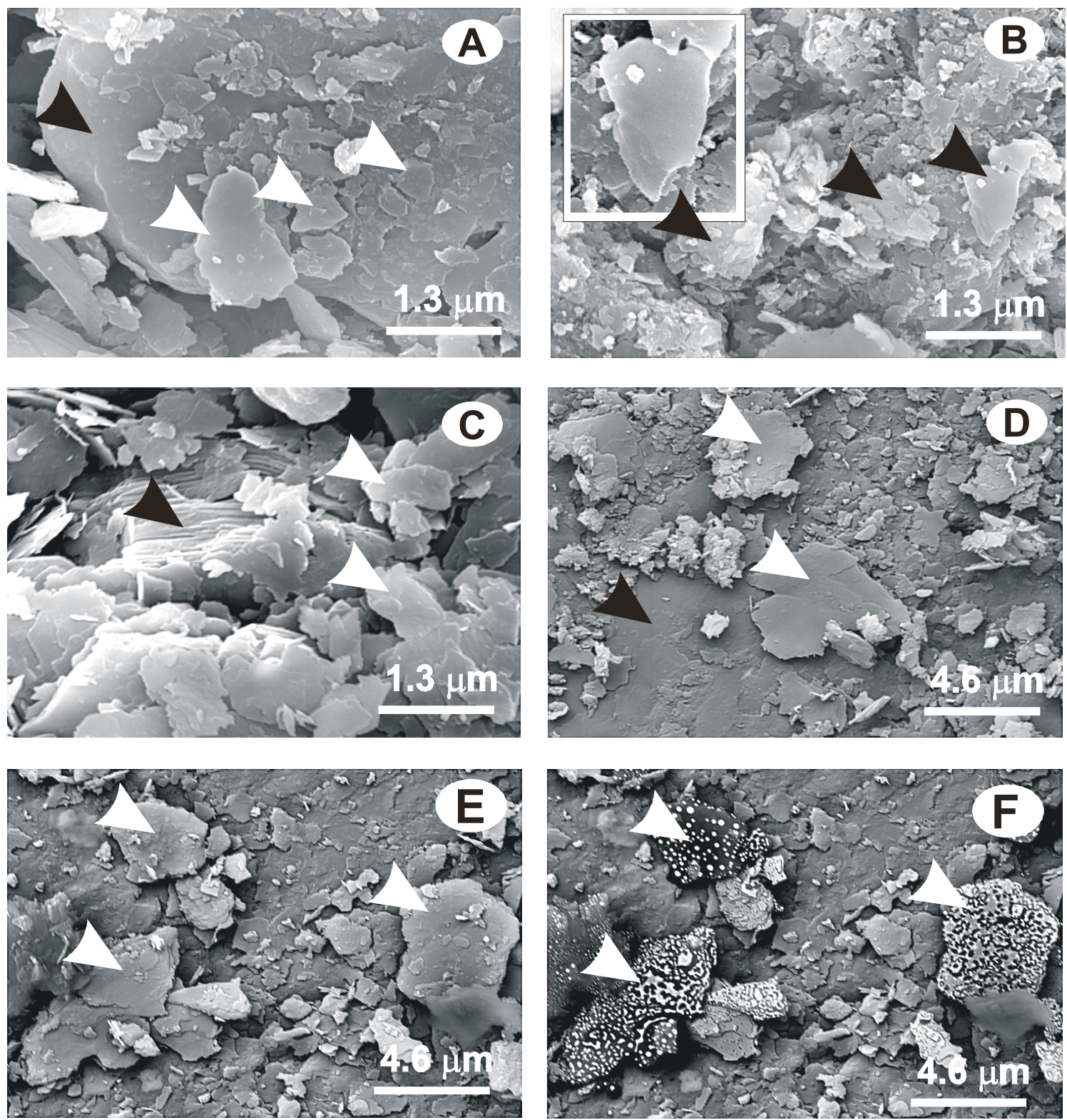

Figure 3. Scanning electron micrographs (A, B and C - secondary electron images; D, E and F-back-scattered electron images). (A) flakes of mica (white arrows) on surface of slate (black arrows), (B) fragments of feldspars (black arrows) with smooth surface (see inset), ( $C$ and $D$ ) mica flakes (white arrows) on surface of mica (black arrows), (E) before and (F) after 20 sec energy dispersive analysis showing electron beam damage and/or transformation/phase change. 
of muscovite (or mica), kaolinite, feldspars and quartz, although the "flakes" appear to contain more muscovite and less feldspars than slate as indicated by the relative intensities at $0.998 \mathrm{~nm}$ and $0.312 \mathrm{~nm}$ regions, respectively (Figure 4). Calcite is indicated by $\mathrm{X}$-ray reflections at 0.302 , $0.190,0.187,0.245,0.227$ and $0.208 \mathrm{~nm}$ re- gions and is present together with "flake" coating on the surface of slate and sandstone (Figure 4). Calcite on the surface of sandstone was also observed (Figure 4). There are also solid phases with structure that is sensitive to electron beam (Figures 3E and F).

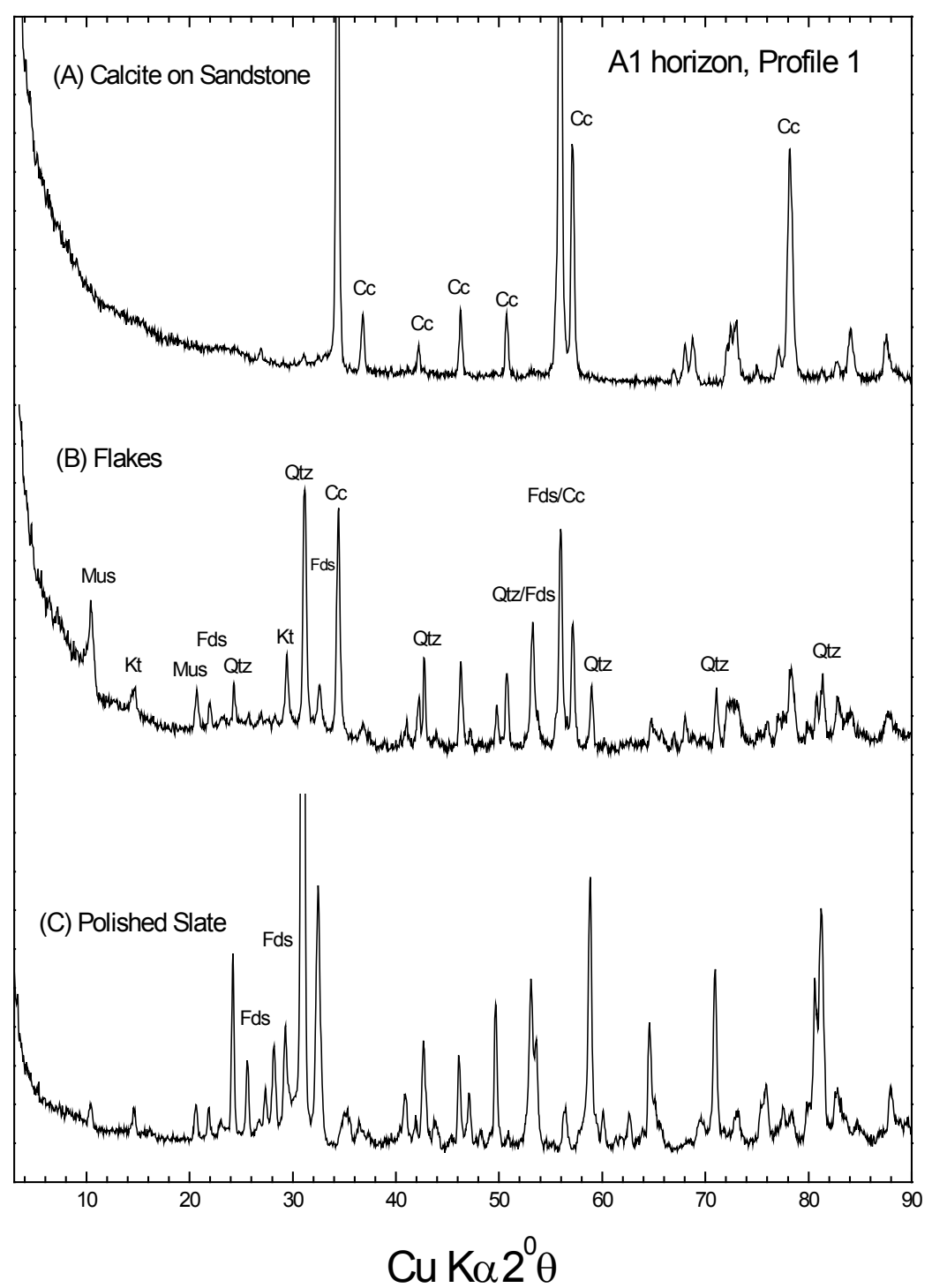

Figure 4. X-ray diffractograms of (A) carbonate on sandstone, (B) randomly oriented "flakes" and (C) slate from A1 horizon of Profile 1; Mus - muscovite (a mica species), Fds - feldspars, Qtz - quartz, Cc - calcite. 


\section{Discussion}

Despite limited amounts of water and the low temperature, continued input/output of matter and energy contribute to the transformation/ breakdown of parent geological materials into soils even in cold and dry environments such as in our study areas (e.g., Mahaney et al. 2001; Etienne and Dupont 2002; Wang et al. 2002; Arocena et al. 2003; Zhang et al. 2003). In a soil system, the flow of matter and energy maybe fast at the molecular level but its manifestation in soil properties varies considerably. Some soil properties transform rapidly ( 1 to $10^{2}$ years), some change at a relatively slow rate $\left(10^{2}\right.$ to $10^{6}$ years) and others evolve over long duration of time ( $10^{4}$ to $10^{6}$ years) (Yaalon 1971 cited in Chadwick and Chorover 2001).

The starting material of soils in our study area is a gray-green and brown sandstone and slate of Lower Triassic and part of the lower Bayan Har formation (IG-CAS 1990; Zhang and Zheng 1996). The materials may have been exposed when uplift of the plateau took place during the Early and Middle Pleistocene. Our discussion of soil formation in this material will be grouped into four basic soil-forming processes namely: addition, removal, translocation and transformation (and all possible combinations) of matter and energy. Intensity and rate of processes also vary with time and space. These processes are regarded as continuous but should be more accurately describe as taking place in pulses over extended periods especially in our study sites where frozen period constitutes significant portion of the year.

\section{- Addition and removal}

There is limited development of a horizon of organic matter accumulation (Ah horizon). Limited vegetative growth in our study area limits the thickness of the A horizon to $<20 \mathrm{~cm}$ and organic matter content $<0.06 \%$ total $\mathrm{C}$. The amounts of total $\mathrm{C}$ in our study areas are much lower compared to those reported by Zhang et al. (2006) with range from $1.47 \%$ in toe of the slope to as high as $3.23 \%$ soil organic $C$ in summit of the slope. The Ah horizon in our study is too thin and contains a very low organic mat- ter content to meet the requirements of a mollic epipedon (Soil Survey Staff 2010). The irregular depth distribution of total N, C in Profile 1 suggests burials of Ah horizons from repeated slumping of soil materials. In Profiles 2 and 3 , total $\mathrm{N}$ hardly changes with depth indicating no accumulation of organic matter on the surface. The development of an Ah horizon is sporadic in places where sparse alpine/meadow vegetation such as Saussurea gnaphalodes, S. hypsipeta, Arenaria bryophylla, Oxytropis densa, Astragalus densiflorus and Carex moorcroftii ( $\mathrm{Li}$ et al. 1996, p. 113) thrive. Despite the meager distribution of vegetation, carbon tied in soils at Qinghai plateau amounts to $\sim 23 \%$ of the total carbon stored in soils of China (Wang et al. 2002). This proportion is seemingly high considering the low amounts of total $\mathrm{N}$ and $\mathrm{C}$ in the study area but soils in other parts of the plateau might have higher organic matter content probably due to slow rate of decomposition process in dry and cold environment. Yang et al. (2008) reported carbon storage of $6.5 \mathrm{~kg} \mathrm{C} \mathrm{m}^{-2}$ in the grassland ecosystems in the Qinghai plateau.

Aeolian deposition of inorganic materials seems not to be significant in our study area. This is indicated by the similarity in particle size distribution as well as the mineral composition of surface layer and the deeper layers of the three profiles. However, there is erosion occurring in the study site as can be seen by occasional dust clouds. This is in agreement with the preliminary results of Yan et al. (2001) indicating that the removal rate of surface soil in the Qinghai plateau is $\sim 3 \mathrm{~mm}$ year ${ }^{-1}$, a rate equivalent to moderate intensity of erosion in the Chinese standard. The depositional areas are probably lower in elevation than our study sites.

\section{- Transformation}

The similarity in the contents of muscovite and kaolinite in horizons among the three soil profiles indicates minimal transformation of clay minerals in the study area. Among others, this is probably due to insufficient amount of water to remove products of weathering or the due to the presence of carbonates that prevented acidic 
weathering. For example, percolating water is needed to decrease $\mathrm{K}^{+}$concentration $<80 \mathrm{~mol}$ $\mathrm{K}^{+} \mathrm{dm}^{-3}$ soil solution to form vermiculite $(2: 1 \mathrm{ex}-$ panding clay) from phlogopite (a mica species) (Hinsinger and Jaillard 1993). Low intensity of biological activity might also be responsible for the lack of mica transformation. Active uptake by plant roots of $\mathrm{K}+$ from the weathering of muscovite is one principal driving force of the transformation of mica to expanding 2:1 phyllosilicates (e.g., Hinsinger et al. 1992; Hinsinger and Jaillard 1993). Minimal root growth of higher plants also implies low distribution of mycorrhizal fungi, another contributor to the transformation of mica to expanding 2:1 phyllosilicates in soils (Hinsinger et al. 1992; Arocena et al. 1999).

Iron oxides are observed in our samples. These oxides might have originated from iron released from ferro-magnesian minerals present in the slate and sandstone, such as pyroxene and amphiboles. Periodic pulses of water (e.g., snow melt) might have caused the reduction and oxidation of minerals leading to the formation of iron oxides. The high $\mathrm{Fe}_{\text {o/d }}$ ratio in Profile 2 indicates that iron oxides are short-ordered minerals such as ferrihydrite (Schwertmann and Taylor 1989). Ferrihydrite may eventually transform to hematite in conditions that promote dehydration processes such as on arid environment. Goethite forms from ferrihydrite in environment containing low organic matter, high $\mathrm{pH}(\mathrm{pH} 3-8)$ and high supply of iron (Schwertmann and Taylor 1989). In Profiles 1 and $3, \mathrm{Fe}_{\text {o/d }}$ ratio rarely exceeded 1.0 suggesting the presence of more crystalline iron oxides compared to Profile 2. The location of Profile 2 on a northeast oriented slope might induce higher transformation of ferromagnesian minerals than in soils on north and southeast oriented slopes.

Low intensity of feldspars transformation is indicated by smooth surfaces observed under the scanning electron microscope (Figure $3 \mathrm{~B}$ ). The absence of distinctive etch "pits" on surfaces of feldspars indicates minimal to absence of chemical weathering. Wu et al. (2005) attributed the slight excess of $\mathrm{Na}$ ions in waters draining from the Qinghai plateau to the minimal weathering of albite. The limited vegetative growth in our study area might have resulted to minimal weathering of feldspars due to minimum production of organic acids (e.g., acetic, aspartic, citric, salicylic, oxalic) that are known to play significant role in release of cations from the weathering of feldspars (Huang 1989).

\section{- Translocation}

The dry environment ( $280 \mathrm{~mm}$ annual rainfall) limits translocation of materials within the soil profile. In addition, Yang et al. (2003) determined that at $4 \mathrm{~cm}$ depth, soils close to our study area are frozen for 172 days. The absence of eluvial horizon, blocky structure and well developed argillans on surfaces of sand grains indicates that lessivage (translocation of clays) is not taking place at significant rate due to lack of percolating water. Colder temperature coupled with limited water at high elevation areas hampers chemical weathering and clay formation, thus the absence of (oriented) clay coatings in soils in elevated areas (Jenny 1935, 1980 cited in Eash and Sandor 1995). We attributed the increased in clay content below IIA2 to lithologic discontinuity rather than lessivage because of the absence of recognizable clay coatings and abrupt decrease in CEC and exchangeable calcium.

However, "flakes" of micaceous and "fragments" of feldspathic minerals coat the surfaces of slate materials are evident in our samples (Figures 3 and 4). These materials are probably formed in place from the mechanical breakdown of parent material. In a dry environment such as our study site, thermal stress (Hall and André 2001) most likely exerted significant influence to the formation of these micaceous "flakes" and feldspathic "fragments". Dilation upon exposure of the bedrock to the surface of the earth due relieved pressure after metamorphism might also contribute to the formation of "flakes" of mica and "fragments" of feldspars. However, the possibility that the micaceous "flakes" and the feldspathic "fragments" were already coating the quartz and feldspars during the formation of sandstone and slate can not be discounted. 
The very low amounts of $\mathrm{Al}_{\mathrm{p}}+\mathrm{Fe}_{\mathrm{p}}$ suggest that podzolization is minimal to non-existent in our study site. This is corroborated by the absence of an eluvial horizon, or a zone of removal and podzolic B horizon. The absence of vigorous vegetation growth and the arid conditions contribute to the absence of well-developed podzolization features. Organic acids necessary for podzolization process could be produced by leaching from plants, decomposition of litter by microbes and exudation by roots, fungi and microorganisms (Lundstrom et al. 2000). High rainfall during the growing season is a characteristic of environment conducive to podzolization (Van Breemen and Buurman 1998) and this is absent in our study site.

Carbonates do not seem to translocate beyond the soil profile in our study site. This is shown by soil $\mathrm{pH}>7.0$ in all horizons and $\mathrm{X}$-ray reflections indicative of calcite observed on the surface of sandstone. The lack of decarbonation processes is probably related to the low amount of rainfall as well as sparse vegetation in the study sites. Wu et al. (2005) reported that most waters draining from the Qinghai-Tibetan plateau are oversaturated with respect to calcite and dolomite, thus limited carbonation processes consistent with our observations. Organic acids from the decomposition of organic materials as well as from microorganisms produce acids that help dissolve carbonates. The calcium carbonates present on slate and sandstone might have formed from water generated during episodic melting of snow and ice or from processes that took place prior to soil formation (i.e., during the deposition of the sandstone). The low amount of percolating water prevents the translocation of carbonates (and clays) to deeper part of the profile.

\section{- Soil classification}

Low temperature (MAAT $=-5.5^{\circ} \mathrm{C}$ ) in our study area restricts many soil-forming processes and resulted to the predominance of Cryosols (IUSS Working Group WRB 2006), or soils formed in permafrost environment (Driessen et al. 2001). These restricted processes result in soil profiles with limited horizon development. Soil horizon in our study sites is limited to ochric epipedon or horizon of slight development (Soil Survey Staff 2010; Driessen et al. 2001) and very slightly developed $B$ horizons. The most prominent feature in the B horizon is the formation of "flakes" of mica and "fragments" of feldspathic minerals. B horizon at our site does not meet the criteria for the cambic horizon (Soil Survey Staff 2010; Driessen et al. 2001). However, 2Bw horizons meeting the criteria for Cambisols are observed by Kaiser (2004) in a soil transect on the Qinghai plateau where the MAAT $=0.9 \mathrm{C}$, a few degrees warmer that the climate in our study area.

Cryosols (IUSS Working Group WRB 2006) are equivalent to the Cryosolic soils in the Canadian system of soil classification (Soil Classification Working Group 1998) and to the Gelisol order in USDA Soil Taxonomy (Soil Survey Staff 2010). Cryosols are found in permafrost regions of the Arctic, Antarctic, sub-arctic zones, sporadically in boreal zone and in temperate mountainous regions in Andes and Himalayas. China has an estimated $1.9 \times 10^{6} \mathrm{~km}^{2}$ of Cryosols in its mountainous areas (Driessen et al. 2001). 


\section{Conclusions}

Our results show that soil-forming processes are barely taking place in Qinghai plateau. The most significant alteration of slate parent material is the formation of micaceous "flakes" and feldspathic "fragments" probably from thermal stress associated with dry and cold environment. Mineral breakdown from chemical processes is limited to the formation of ferrihydrite and other Fe oxyhydroxides while mechanical breakdown is shown by smooth surface and angular shaped of feldspar minerals. The presumed influence of thermal stress in the breakdown of mica and feldspathic minerals constituted the most significant mechanical breakdown of mineral transformation in our study area. Our results showed minimum decarbonation, oxidation and reduction of iron, lessivage and podzolization processes. Soils in our study area are classified as Cryosols using the World Reference Based (IUSS Working Group WRB 2006) and Gelisols under US Soil Taxonomy (Soil Survey Staff 2010).

\section{Acknowledgements}

We wish to thank the Natural Siences and Engineering Research Council of Canada and the Chinese National Science Foundation for the financial support to carry out this study. The Chinese Academy of Sciences is also acknowledged for logistical support as well as C. Chisholm and D. Dick for their assistance in laboratory analysis.

\section{REFERENCES}

- Arocena JM, Glowa KR, Massicotte HB, Lavkulich L. 1999. Chemical and mineral composition of ectomycorrhizosphere soils of subalpine fir (Abies lasiocarpa (Hook.) Nutt.) in the Ae horizon of a luvisol. Can J Soil Sci. 79:25-35.

- Arocena J, Zhu LP, Hall K. 2003. Mineral accumulations induced by biological activity on granitic rocks in the Qinghai Plateau, China Earth Surf. Processes Landforms 28:1429-1437.

- Beyer L, Bölter M. 2000. Chemical and biological properties, formation, occurrence and classification of Spodic Cryosols in a terrestrial ecosystem of East Antarctica (Wilkes Land). Catena 39:95-119.

- Bockheim JG. 1997. Properties and classification of cold desert soils from Antarctica. Soil Sci Soc Am J. 61:224231.

- Buol SW, Southard RJ, Graham RC, McDaniel PA. 2003. Soil genesis and classification. $5^{\text {th }}$ edition. Ames, lowa: lowa State University Press.

- Campbell IB, Claridge GGC. 1987. Antarctica: soils, weathering processes and environment. Developments in Soil Science 16. Amsterdam: Elsevier.

- Chadwick OA, Chorover J. 2001. The chemistry of pedogenic thresholds. Geoderma 100:321-353.

- Driessen P, Deckers J, Spaagaren O, Nachtergaele F. 2001. Lecture notes on the major soils of the world. Rome, Italy: FAO-United Nations, Publishing and Multimedia Services.

- Eash NS, Sandor JA. 1995. Soil chronosequence and geomorphology in semi-arid valley in the Andes in southern Peru. Geoderma 65:59079.

- Etienne S. 2002. The role of biological weathering in periglacial areas: a study of weathering rinds in south Iceland. Geormorphology 47:75-86.

- Etienne S, Dupont J. 2002. Fungal weathering of basaltic rocks in a cold environment (Iceland): comparison between experimental and field observations. Earth Surf Process Landforms 27:737-748.

- Hall K, Otte W. 1990. Observations regarding biological weathering on nunataks of the Juneau Icefield, Alaska. Permafrost and Periglacial Processes 1:189-196.

- Hall K, André MF. 2001. New insights into rock weathering as deduced from high-frequency rock temperature data: An Antarctic study. Geomorphology 41:23-35. 
- Harris SA, Zhiju C, Guodon C. 1998a. Origin of a bouldery diamicton, Kunlun Pass, Qinghai-Xizang Plateau, People's Republic of China: gelifluction deposit or rock glacier. Eart Surf Processes Landforms 23:943-952.

- Harris SA, Cheng G, Zhao X, Yongqin D. 1998b. Nature and dynamics of an active block stream, Kunlun Pass, Qinghai province, People's Republic of China. Geogr Ann. 80:123-133.

- Hendershot WH, Lalande H, Duquette M. 1993. Soil reaction and exchangeable acidity. In: Carter $\mathrm{M}$, editor. Soil sampling and methods of analysis. Boca Raton, USA: P Lewis Publishers. p. 141-146.

- Hinsinger P, Jaillard B, Duffey JE. 1992. Rapid weathering of a trioctahedral mica by the roots of ryegrass. Soil Sci Soc Am J. 56: 977-982.

- Hinsinger P, Jaillard B. 1993. Root-induced release of interlayer potassium and vermiculitization of phlogopite as related to potassium depletion in the rhizosphere of ryegrass. J Soil Sci 44: 525-534.

- Huang PM. 1989. Feldspars, olivines, pyroxenes, and amphiboles. In: Dixon JB, Weed SB, editors. Minerals in soil environments. $2^{\text {nd }}$ ed. Madison, WI: SSSA Book Series No. 2. p. 975-1050.

- Institute of Geography, Chinese Academy of Sciences (IG CAS). 1990. The atlas of Qinghai-Tibetan Plateau. Beijing, China: Sciences Press. p. 21 (in Chinese).

- IUSS Working Group WRB. 2006. World reference base for soil resources 2006. $2^{\text {nd }}$ edition. Rome: FAO, World Soil Resources Reports No. 103.

- Kaiser K. 2004. Pedogeomorphological transect studies in Tibet: Implications for landscape history and present day dynamics. Prace Geograficzne 200:147-165.

- Kalra P, Maynard DG. 1991. Methods manual for forest soil and plant analysis. Information Report. NOR-X-319. Edmonton, AB: Forestry Canada.

- Li B, Gu G, Li S, editors. 1996. Physical environment of Hoh Xil Regioin, Qinghai. Beijing: Science Press (in Chinese).

- Lundstrom US, Van Breemen N, Bain D. 2000. The podzolization process: a review. Geoderma 94:91-107.

- Mahaney WC, Dohm JM, Baker VR, Newsom HE, Malloch D, Hancock RGV, Campbell I, Sheppard D, Milner MW. 2001. Morphogenesis of Antarctic Paleosols: Martian Analogue. Icarus 154:113-130.

- Matsuoka N. 1995. Rock weathering process and landform development in Sør Rondane Mountains, Antarctica. Geomorphology 12:323-339.
- Ross GJ, Wang C. 1993. Extractable Al, Fe, Mn and Si. In: Carter MR, editor. Soil sampling and methods of analysis. Boca Raton, USA: Lewis Publishers. p. 239-246.

- Schwertmann U, Taylor RM. 1989. Iron oxides. In: Dixon JB, Weed SB, editors. Minerals in soil environments. $2^{\text {nd }}$ edition. Madison, WI: SSSA Book Series No. 2. p. $379-438$

- Soil Classification Working Group. 1998. The Canadian system of soil classification. $3^{\text {rd }}$ edition. Ottawa, Canada: NRC Press.

- Soil Survey Staff. 2010. Soil taxonomy: a basic system of soil classification for making and interpreting soil surveys. $11^{\text {th }}$ edition. USDA Agriculture Handbook No. 436. Washington DC, USA: US Govt Printing Office.

- Theisen AA, Harward ME. 1962. A paste method for preparation of slides for clay mineral identification by X-ray diffraction. Soil Sci Soc Amer Proc. 26:90-91.

- Van Breemen N, Buurman P. 1998. Soil formation. Dordrecht, The Netherlands: Kluwer Academic Press.

- Wang GX, Qian J, Cheng GD, Lai M. 2002. Soil organic carbon pool of grassland soil on the Qinghai-Tibetan Plateau and its global implication. Sci Total Environ. 291:207-217.

- Wu Y, Cui Z, Liu G, Ge D, Yin J, Xu Q, Pang Q. 2001. Quaternary geomorphological evolution of the Kunlun Pass area and the uplift of the Qinghai-Xizang (Tibet) Plateau. Geomorphology 36:203-216.

- Wu L, Huh Y, Qin J, Du G, Van der Lee S. 2005. Chemical weathering in the Upper Huang He (Yellow River) draining the eastern Qinghai-Tibet Plateau. Geochim Cosmochim. 69:5279-5294.

- Yan P, Dong ZB, Dong GR, Zhang XB, Zhang YY. 2001. Preliminary results of using ${ }^{137} \mathrm{Cs}$ to study wind erosion in the Qinghai-Tibet Plateau. J Arid Environ. 47:443-452.

- Yang M, Yao T, Gou X, Koike T, He Y. 2003. The soil moisture distribution, thawing-freezing processes, and their effects on the seasonal transition on the QinghaiXizang (Tibetan) Plateau. J Asian Earth Sci. 21:457-465.

- Yang Y, Fang J, Tang Y, Ji C, Zheng C, He J, Zhu B. 2008. Storage, patterns and controls of soil organic carbon in the Tibetan grasslands. Global Change Biol. 14:1592-1599.

- Zhang Y, Zheng X, editors. 1996. Geological Evolution of the Hoh Xil Region, Qinghai. Beijing, China: Sciences Press. p. 9-14 (in Chinese)

- Zhang DD, Jim CY, Peart MR, Chi C. 2003. Rapid changes of precipitation $\mathrm{pH}$ in Qinghai Province, the northeastern Tibetan Plateau. Sci Total Environ. 305:241248. 
- Zhang JH, Liu SZ, Zhong H. 2006. Distribution of soil organic carbon and phosphorus on an eroded hillslope of the rangeland in the northern Tibet Plateau, China. Euro J Soil Sci. 57:365-371.

- Zhao XF. 1994. On the cryogenic weathering and the environment change in the permafrost region of QinghaiTibet Plateau. Ph.D. Thesis. Lanzhou Institute of Geocryology and Glaciology. Beijing: Chinese Academy of Science (in Chinese).

- Zhou YW, Guo DX, Qiu GQ, Cheng GD, SD. 2000. China Permafrost. Beijing: Science Press (in Chinese). 